Citizenship Studies,

Vol. 10, No. 3, 349-372, July 2006

Routledge

Taylor \& Francis Group

\title{
From the Morality of Living to the Morality of Dying: Hunger Strikes in Turkish Prisons
}

\author{
GÜRCAN KOÇAN* \& AHMET ÖNCÜ** \\ *Department of Humanities and Social Sciences, Faculty of Science and Letters, Istanbul Technical University, \\ Maslak Istanbul, Turkey, **Faculty of Management, Sabanci University, Orhanli, Tuzla, Istanbul, Turkey
}

\begin{abstract}
Political hunger strikes have been part of the debates on human rights in many countries around the world. This paper explores the preconditions for and motives behind hunger strikes in Turkey by conceiving the hunger strikers as a part of citizenship politics through which strikers not only express their views against certain common issues, but also declare total opposition to an unjust condition within their political community. The paper focuses on the question of why some such "citizens" choose to participate in hunger strikes, which appears as an individual commitment to achieve a certain common objective. In doing so, the meaning of the experiences of hunger strikers and their universal right to live are elaborated in relation to their political and moral views. Hunger strikes are suggested to be seen as voluntary fasting, undertaken as a means of civil disobedience against an injustice within the context of citizenship. As examples of non-violent political acts, hunger strikes are not only part of citizenship politics but also expressions of commitment to achieving one's goals through non-aggressive means for the common good of all citizens. Moreover, they can also be considered examples of martyrdom/heroism because hunger strikers altruistically risk their life for a public cause. As a particular altruistic act, hunger strikes can also be viewed as an effective form of communication directed toward fellow citizens. Moreover, they are expressions of self-determination for having control over and for one's own life conditions. Finally, hunger strikes can be conceptualized as a struggle for transforming the configuration of structures and practices of citizenship about which one is passionately concerned. In this context, hunger strikes seem to be struggles for recognition in a relationship between two subjects, in which one subordinates the other.
\end{abstract}

Hunger strikes, such as those by Mahatma Gandhi in India and Bobby Sand in Ireland, have sometimes been used in different places around the world as a non-violent means to express resistance and to encourage a change in public policy. Both Gandhi and Sand attempted to use non-violent expression to bring about a change in their respective political environments. Gandhi's approach to the use of hunger strikes rested on an understanding that it is one of the "mightiest" forms of civil disobedience, which both attracts attention and garners respect. Nevertheless, the hunger strike by Bobby Sand and

Correspondence Address: Gürcan Koçan, Department of Humanities and Social Sciences, Faculty of Science and Letters, Istanbul Technical University, 34669 Maslak, Istanbul, Turkey. Fax: + 90212285 6386; Tel.: + 90 212285 3295; Email: kocan@itu.edu.tr 
his "comrades" that ended in their deaths has, unsurprisingly, attracted far more attention than those ending with one side or the other yielding. The death of these hunger strikers resulted in the Irish people declaring them as martyrs. They are seen as heroes because they sacrificed their life for their common cause. They accepted death with tremendous courage, but they did not essentially seek it. While the motivations behind their decision to stare death in the face may be difficult to understand, it is clear that it constituted a highly effective form of political action.

Political hunger strikes have been part of the debates on human rights in Turkey for nearly two decades. Public awareness of hunger strikes was amplified by the "death fasting" in 1984 by some "political prisoners" in the Metris penitentiary in Istanbul. Political prisoners, during those hunger strikes, demanded the abolishment of torture and the right to wear civilian clothes rather than prison uniforms. The government at the time decided to maintain its policies regarding prison rules. As a result, four political prisoners died from the hunger strike. Later in 1996, hunger strikes for similar demands repeatedly took place in Turkish prisons. Twelve more of the prisoners died as a result of the continued hunger strikes. On 20 October 2000 the longest and most deadly hunger strikes, coordinated jointly by 11 of the radical left organizations, began protests in prisons throughout Turkey. Imprisoned members of the Revolutionary People's Liberation PartyFront (DHKP-C), the Communist Party of Turkey-Marxist-Leninist (TKP-ML) and the Communist Workers Party of Turkey (TKIP) called for a struggle against the proposed regulation that aims at transferring prisoners from large, open dormitory-style facilities to new single cells, which are called high security F-Type isolation cells. The authorities, overwhelmed by the large number of prisoners, reasoned that they could better maintain order and discipline by isolating inmates from each other. However, the prisoners expressed fear in response to the idea of being moved to smaller cells, even though they were allegedly going to be placed in new buildings with better facilities. The relative isolation, they emphasized, would render them vulnerable and unprotected. Indeed their claims were valid as routine acts in contravention of human rights were commonly practiced at that time and reported by official and non-official human rights watch organizations. Thus, the claim that sharing a common area together would protect them from these abuses has some credence. The hunger strikes continued over a period of four years, claiming at least 120 lives.

This paper aims to explore the preconditions for and motives behind hunger strikes in Turkey by conceiving the hunger strikers as citizens whose rights, responsibilities and freedoms are restricted because of their "criminal" status. The paper focuses on the question of why some such "citizens" choose to participate in hunger strikes, which appears as an individual commitment to achieve a certain common objective. In doing so, it aims to understand the meaning of the hunger strikers' experiences versus their universal right to live in terms of their political and moral views. The fundamental dilemma that arises from this opposition is whether it is more important to live for one's own "self" or to die for the common good of others, thus correcting for perceived injustices by sacrificing one's individual life for a political cause. This is indeed what makes hunger strikes an issue that must be addressed in citizenship debates. Given that citizenship refers to a political community of individuals bounded by a contract of rights, freedoms and responsibilities, political acts that claim to augment the common good are unavoidably part of politics of citizenship. The question then is whether some political acts aimed at the common good can be categorically ruled out by reference to the criminal status of the citizens. 
The hunger strikes that this paper examines are indeed part of citizenship politics through which strikers not only express their views against certain common issues, but also declare total opposition to an unjust condition within their political community. As political acts, hunger strikes are acts of communication, acts of negotiation and acts of teaching, all of which inexorably depart from a particular citizenship and the ways in which it is practiced (Williams, 2001, p. 287). As an expression of citizenship, hunger strikes aim to make other citizens aware of failures in their political system, and provide a means of learning by an astonishing example. That is, by voluntarily giving up one's most fundamental human right, the right to live. In this context we may consider hunger strikes an effective means of encouraging more citizens to become critically aware of unjustified rules.

\section{A General Overview of the Turkish Prison System}

To understand the issue of hunger strikes in a broader political sense with respect to the notion of citizenship, it is necessary to analyze the existing conditions of the Turkish prison system. Nevertheless, we first need to clarify how we link the concept of "imprisonment" or the "right to punish" to the notion of "crime". Imprisonment is mostly considered a deterrent against crime and justified by reference to the conviction that removal of certain freedoms of criminals and separation of them from non-criminals by incarceration is a service for society. Surely, crime is an act against somebody or something. But what is a crime? And who is a criminal? Are all crimes the same in terms of their perceived threat to society? Can all crimes be conceived as a threat to society? What about those "crimes" conducted with the belief on the part of the conductors that they are indeed doing a "good" for society by their acts? When we delve into such questions we can recognize that although the criminality of an act is socially and politically contextual, the rationales that justify certain acts as criminal are very much universal. One of these universal rationales is seeing crime as doing harm to somebody who is considered innocent. Since the law typically defines harmful acts, however, this is tantamount to saying that crime is an act committed in violation of a law. Therefore, almost all criminal acts eventually boil down to causing harm to the political community, given that the law is the legal expression of a political contract among a group of individuals, which defines certain rights in return for sacrificing certain freedoms that might have been enjoyed by not accepting the contract (Rousseau, 1988; Locke, 1993; Hobbes, 1994). In this view, the state is considered the institution that puts in force the contract by making a claim to the legitimate authority for the use of power such as imprisonment (Weber, 1947, pp. 324-325). This means that the state is given traditional, rational and charismatic grounds for implementing the legal capacity to chase the violators of the law and prosecute them. Thus, a crime is always an act against the state; that is to say, it is an act conducted essentially against the enforcer of the law. Here it is possible to differentiate criminal acts in terms of whether they are direct or indirect acts against the state. Any act that is injurious to a person according to the law is an indirect criminal act against the state. This sort of crime does not necessarily aim at eliminating the contract, and thereby denying the legitimacy of the state as the implementer of the law. It is only those acts that directly aim to break down the capacity of the state as the enforcer of the law, hence disapproving the contract, that can be viewed as direct crimes against the state. Needless to say, the latter are political in nature and their criminality is context bounded. 
In other words, direct criminal acts against the state cannot be universalized or generalized across different states. What is considered a citizenship right or freedom in a particular state might be seen as a crime against the state in another one.

For our purpose, the so-called direct crimes against the state are interesting simply because they are committed on the basis of the belief that the state is illegitimate and hence its classifications of acts as crimes must be refuted by violating its laws. We have to admit that this is an issue well beyond the intentions and limits of this paper. Yet it is an important part of our discussion, as it reminds us that we are straddling the difficult moral riddle that has always occupied a central place in political and moral philosophy. The moral riddle that we are referring to is the question of crime in such cases when the right to deliver punishment by the state is challenged by certain criminal acts in order to change the moral and political order of society. The riddle becomes especially hard to tackle when there is no harm being done to any person, but instead applied to one's own self. In what follows, without claiming to resolve the riddle, we consider how self-inflicted direct crimes against the state are political acts for changing the legal and political configurations of a state and hence are claims for changing the boundaries of rights and freedoms, in other words, citizenship. It is in fact the latter feature of hunger strikes in Turkish prisons that connects them to the debates of citizenship.

Having said this, we begin with a sociological remark on the special meaning of imprisonment in Turkey and the complex relations it has with the citizens. The first thing to note is that prisoners can be understood in terms of the expressed feelings of pity and compassion. Such feelings often find a strong voice in poetry, novels, songs and paintings. As one of the most famous Turkish poets, Nazım Hikmet, puts it, imprisonment is a difficult art and prisoners are artisans. The feeling of pity often rests on the belief that imprisonment is not the result of the prisoner's own culpable actions (Nussbaum, 1996, p. 31). Such feelings are felt because imprisonment is seen as a result of fate and not the wrong choices that a person makes (Nussbaum, 1996, p. 33). For this reason, prisoners are often called "prisoners of fate". These feelings aid in the release of guilt and transform those experiences into life encounters; causing people to accept life as it is, was, and will be or what Nietzsche referred to as "amor fati". Nietzsche's notion of amor fati implies that people are not in control of their actions and that they are predestined to live a course of events. In other words, humans lack the capacity to self-determine their lives and thus they have to endure what comes to them as their determined fate. Therefore, being incarcerated is not felt as the result of one's actions, but rather that person's uncontrollable fate. For the people of Turkey, those that are imprisoned experience an amplified sense of fate. They often assert amor fati as a normative approach towards life. Amor fati is the love of life as it is. It makes people recognize that they exist as parts of a complex whole and embrace life as a special experience without regret or resentment, but only the love of fate. As Nietzsche says:

Amor fati: let that be my love henceforth! I do not want to wage war against what is ugly. I do not want to accuse; I do not even want to accuse those who accuse. Looking away shall be my only negation. And all in all and on the whole: some day I wish to be only a Yes-sayer. (Nietzsche, 1974, p. 276)

Amor fati is a threshold for prison life where determinism is understood as human incapability and highlighted to provide comfort and support in their daily lives as inmates. 
Prisoners assert themselves as not necessarily guilty, although they are aware of their crimes, but it is their fate that brought them to this point and they have a feeling that they should be treated as normal individuals for that very reason. In the eyes of prison inmates, the prison appears to contain a binary division consisting of one set of people seen as innocent, namely, the inmates, and on the other side the penal system comprising the hierarchy of prison administration responsible for deploying technologies of punishment and discipline. As a specialized institution the penitentiary system involves a set of corrective practices comprising a whole set of instruments, techniques, procedures and applications geared to disciplining and punishing inmates (Foucault, 1979, pp. 307-308). As in other societies, Turkish prisons are also rationally designed to punish and discipline people who have been convicted of crimes. Prisons in Turkey face a variety of problems in executing their capacity as disciplining and punishing institutions. An array of economic, political, social and cultural transformations creates a new context of "deviance" in society, which applies pressure on the existing criminal justice system. Further problems relating to overcrowding, insufficient infrastructure, financial shortcomings, inefficiency of legislation and inadequacy of staff escalates the bottleneck in the criminal justice system. In the Turkish criminal justice system, prisons are legitimized and necessary institutions first for the protection of society (removal), second for the prevention of crime (deterrence), third for the retribution of criminals (retribution), fourth for the sake of justice (getting what one deserves or punishment) and fifth for the rehabilitation of inmates (rehabilitation).

In Turkey, prisons are funded and operated by the state. There are 503 penitentiaries with a 70,994 inmate capacity (see Appendix, Table 1). ${ }^{1}$ These institutions administratively are classified into two groups. The first group is referred to as organized penitentiaries. Organized penitentiaries, which are located in the big city centers with felony courts, have broader capacity. The second group is referred to as not fully organized penitentiaries. These are located in small towns and have small capacities. Turkish penitentiaries can also be divided into two groups according to their architectural form. The first form is the dormitory/ward style (in Table 1 all but F-Type prisons) and they make up the majority of Turkish penitentiaries. These dormitories, which normally can accommodate 30 to 100 inmates, are frequently overloaded beyond their capacities. This is in sharp contrast with the cell system based on the form of isolating inmates. This second type includes the F-Type prison, which were constructed to impose the regime of isolation in the early 1990s. There are 11 F-Type prisons with the capacity to hold 4212 inmates; and these are based on separate cells for one or three persons.

In 2004, 59,230 people were placed into penitentiary institutions that are categorized according to different types of offenders (see Appendix, Table 2). In the same year about 22,000 new inmates were admitted, while approximately the same number of inmates were released from the prisons. This observation suggests that the turnover rate is relatively high as compared to the total number of inmates at a given time (in other words, convicted offenders serve short terms and are then released) (see Appendix, Table 3). It is important to note here that although the percentage of citizens imprisoned out of the total population in Turkey is relatively low by international standards (in other words, $0.1 \%$ as compared to $0.7 \%$ in the USA; Lippke, 2002, p. 122), the high turnover rate reveals that people's experience of prison life is as high as elsewhere. In other words, there is a large number of citizens going through the process of "prisonization" and hence absorb the values and norms of prison life. Another important point to note is that the majority of 
those experiencing the "prisonization" are the less educated citizens of the country (see Appendix, Table 4). Thus, as is true in most other countries, there is a negative association between breaking the law and the level of education. As less educated citizens are more prone to act in violation of law, the failure of the Turkish state in providing the conditions of education for all citizens may lead one to argue that not only convicted offenders, but also the state itself can also be held responsible for crimes. From the point of view of the state it is expected that those going through "prisonization" can change their understanding of life, behavior and their traits in regard to self-control, decision-making and integrity. However, the high turnover rate in Turkish prisons raises questions both about the validity of that expectation and the success of the criminal justice system in reintegrating those who have been incarcerated into the political community as "good" citizens.

Administrators of the criminal justice system differentiate offenders first according to general and terror crimes and second according to being convicted or in a situation of remand (see Appendix, Table 5). ${ }^{2}$ The criteria for assigning inmates to different custody levels include the person's offense, prior record, history of violence, past institutional behavior, and sentence length (see Appendix, Table 6). In Turkey, the government uses a multilevel complex scale (political, ordinary, gender) to determine an inmate's custody level. Conventional custody levels are minimum-security, medium-security, and maximum-security. Some prisons are designed exclusively for women and children. Minimum-security prisons are designed to house low-risk, first-time offenders convicted for non-violent crimes. Housing in minimum-security facilities is often dormitory-like, and the open grounds and buildings of a minimum-security facility resemble an agricultural site. Inmates assigned to such facilities are expected to work in agricultural fields and trusted to comply with open prison rules. Medium-security institutions are called half open prisons. Half open prisons also have dorms that accommodate 20 to 100 inmates in each ward. At medium-security facilities, freedom of movement, privileges (such as participation in sporting events), and access to various educational, vocational activities is not greatly restricted. ${ }^{3}$ Prison officials are more flexible allowing visitation hours. High security facilities house both extremely violent and terror related offenders and are operated by both dorm and individual cell systems. High security facilities are designed to significantly restrict the freedom of movement of inmates. Prison officials can limit visitation and carefully monitor communication between inmates and visitors. These facilities were overwhelmed by massive overcrowding, decaying physical infrastructure, inadequate staff, lack of medical care and corruption. People who are housed in cells suffer severe loss of love, care and solidarity. Their ties of friendship are relentlessly disrupted and typically replaced by the opposite. In 2004, 3,880 prisoners are classified by terror related crimes and housed in high security facilities.

\section{Hunger Strikes in Turkish Prisons}

Hunger strikes can be considered in relation to social and political movements in Turkey (Koçan \& Öncü, 2005). Not surprisingly hunger strikes in Turkish prisons are linked to an extensive social network of individuals and organizations inside and outside prisons such as human right activists and intellectuals, various sorts of resisters and members of radical left parties, cultural and religious organizations (for example, Alevi Associations), the Bar Associations, the Medical Association of Turkey (TAB), Human Right Association (IHD), 
Union of the Chambers of Engineers and Architects of Turkey (TMMOB) and the various associations representing the families of prisoners like TAYAD (Solidarity Association of Prisoners' Families). These individuals and organizations share a left-wing political identity, which is commonly called either "revolutionary democrat" or "revolutionary patriot" in the Turkish political language game, and constitutes the very foundation of the political movement aiming to establish a "democratic socialist" society and polity in Turkey (Öncü, 2003a). In this sense, hunger strikers are connected with a larger political project for social and political change, which attempts to bring major transformations in the interactions among social, political and economic realms of Turkey (Öncü, 2003b). Thus, hunger strikers' unmediated involvement with such a political movement oriented towards an alternative society provides them with a normative ideal, for which one can devote his or her whole existence. It is important to recall that this utopia has evolved in the course of the history of social struggles in modern Turkey and has a battery of accumulated symbols, ideas, rhetoric and cultural orientations (Öncü, 2003c). One such cultural orientation is the disposition to resist "oppression" (zulüm), especially the one that is wielded by the state. One of the roots of this particular orientation can be found in the Alevi religious community and faith, from which left ideologies in Turkey draw many ideas (Koçan \& Öncü, 2004). The state does not accept Alevism as a separate religion, but rather includes it as part of Islam. For hundreds of years Alevis have struggled against persecution, while carefully hiding their identities in the public sphere. Needless to say, a resistance culture has evolved from this history of struggle. Thus, it is not accidental to see that hunger strikers are mostly from the Alevi background.

The problems pertaining to Turkish prisons have occupied an important place in the political agenda of not only the left but also almost all sectors of Turkish society. However, heightened controversy over problematic circumstances in prisons has taken place over the last 10 years. Government authorities perceive that these problems, currently experienced in Turkish prisons, are the direct consequences of the ward system and their conditions. For government authorities, the ward system in prisons poses a threat to the established political and legal order. They argue that these shortcomings result from overcrowded dormitories, thus making it impossible to prevent practices such as tunnel digging, escapes, riots, hostage taking, ransom taking, bullying and gambling. For these reasons, in 1991 the Turkish State planned to spend 60 million US dollars in order to build 17 F-Type prisons in accordance with requirements based on Article 16 of the Anti-Terror Law. Article 16 states that those sentenced of committing crimes defined by this law are to be implemented in special prosecution institutions built as single or three person cells in order to prevent inter-inmate "communication and relationships". The government argued that the introduction of F-Type single cell prisons was justified by the UN minimum prison standard rules, the European Council's prison rules and the recommendations made by the European Committee for the Prevention of Torture and Inhuman or Degrading Treatment or Punishment (CPT/Inf (99), 23 February 1999).

The building of F-Type prisons destroys the social setting of the ward system that provides inmates convicted of terror related crimes with a convenient ideological working milieu. High security "F-Type" prisons, where inmates are housed in cells rather than open dormitories, focuses on introducing absolute isolation allowing complete control and break up of social solidarity. The constructions of F-type prisons were first tendered in 1997. F-type prisons are constructed covering an area of 50,000 square meters. They consist of 103 rooms, each accommodating three inmates and 59 single rooms, having a 
total capacity of 368 inmates. The width of the rooms accommodating three inmates measures 25 square meters on one level and 25 square meters on an upper level. The outdoor area for this part is 50 square meters in width. The F-type prisons have five blocks. The administrative body is located in the first block, while the others are allocated for prisoners. There is a closed circuit monitoring center to record daily activities (head counting, health care, visits, hearings, releases, meetings, and so on) and supervise the passing from the administrative block to the prison blocks. In the monitoring center, consisting of two floors, there are 41 monitored screens and a server computer.

After the completion of the construction of only three such F-Type prisons, they have immediately come under the close scrutiny of wider public discussion in the midst of prison riots and protests on a massive scale. Many prisoners across Turkey went on hunger strikes in protest of these F-Type prisons. On 19 December 2000, the security forces intervened in 20 prisons to end the hunger strikes by force. Thirty prisoners and two soldiers died as a result of these operations. Hundreds of prisoners were transferred to the newly built F-Type prisons, where they have been held in isolation ever since. Up until 2005, in which protests and hunger strikes against F-Type prisons are still continuing both outside and inside prisons, a total of 120 people died as a result of these hunger strikes. While some were killed by direct police intervention, most of the remaining have died because of their willingness to fast until death. Indeed, those who participated in this form of protest labeled their actions "death fasting" (ölüm orиси).

As mentioned at the beginning of this paper, prison has a special and positive meaning in Turkey. This is very much so in the case of those who are categorized as "political" and "terror" criminals by the state. For these people, fighting against oppression is a legitimate response to their daily experiences in social life. Thousands of people have indeed galvanized a section of the population, particularly in urban working class districts, where people are distressed by various forms of repression that is utilized as a method of social control by the state. When we look closely at the sociological features of these people, it's not surprising that they are largely coming from those sections of the society that are economically, socially and ethnically disadvantaged. Because they think that their struggles are in fact just, and that being incarcerated is evidence for their honorable acts for the "good" they do not necessarily have a negative perception of prison. On the contrary one may even argue that for most of them being inside is somewhat expected and an important stage in their struggles. Using again the notion of amor fati, they see their lives as being predestined to fight against oppression and for the removal all the unjust causes that seem responsible for the sorrow and despair for themselves and their fellow people. At the same time the traditional dorm-like setup, by providing the social possibility to meet and discuss and share and educate one another, adds to this positive disposition of being inside. It is here that the introduction of the F-type prison in their lives poses a very real break and shift in their perception and conception of "prison". The F-type prisons by humiliating and removing their social capacities destroys that feeling of "honor" associated with being incarcerated. So there is an existential base for their protests.

The F-type prison rests on a particular technique of power and discipline. It works openly in two ways. First, it utilizes the idea of separation as an organizing principle of power and discipline. This leads prisoners to behave not in a "communal" but rather in an "individual" way of acting. Second, it employs surveillance. Surveillance is an important practice of power that is obtained through an architectural system. In his analysis of "different technologies of power", Foucault emphasizes the structural design of prison 
systems. He asserts that structural design makes possible hierarchical observation. He describes hierarchical observation of prisons as Panopticon. The Panopticon design was developed by Jeremy Bentham, who proposed a sketch of the ideal prison as a circular architectural system with a tower in the center (Bentham, 1995). The thoughts behind the Panopticon are, first, to divide the prison into individual cells; second, to watch without being seen; and finally, to watch a large area. The idea is to create an environment where "the penetration of regulation into even the smallest detail of everyday life through the mediation of complete hierarchy assures the capillary functioning of power" (Foucault, 1979, p. 198). In other words, Panopticon plays an important role in how power is exercised and, consequently, in how the identities of prisoners are constituted. Here power is dispersed throughout the institution and its miniscule apparatus. The technology of control is everywhere within the institution and exerts its disciplinary impact without any mediation directly on the separated individuals. When Panopticon in prisons functions optimally, it is the feeling of being watched that has been internalized by the inmates. The inmates can be caught up in a power situation of which they are themselves the bearers of control and discipline. Hence inmates become the principle of their own denial. This also prevents prisoners from developing a sense of responsibility, autonomy, and self-respect to become motivated to actively strive to be a dignified human being.

In this context, a brief digression on Kant's notions of autonomy and dignity in connection with the hunger strikes is in order before we move on to the next section. As expressed in Kant's Groundwork of the Metaphysics of Morals, autonomy corresponds to free will: "autonomy of the will is that property of the will by which it is a law to itself (independently of any property of objects of volition). The principle of autonomy is, therefore: to choose only in such a way that the maxims of your choice are also included as universal law in the same volition" (Kant, 1998, p. 47). In this context, following the basic Kantian position we may suggest that a moral community must provide a source of autonomy and thereby dignity through the role of moral being independent of other roles and social locations. This is equivalent to conceiving all human beings as rational beings endowed with free will and dignity, because they can be autonomous and therefore they should be treated with respect for realizing these abilities. In the "universal law" and "end in itself" formulation, Kant outlines two ways of treating other people. First, he thinks law should be universal with respect to reason. For him, reason is a universal being and exists for all people, so morality of actions too should be universal. This means that when people make their mind up for acting, they should act on a maxim that others could adopt and act on. Second, Kant thinks that people must not use others as a means for their "ends". For this reason, he contends: "all rational beings stand under law that each of them is to treat himself and all others never merely means but always at the same time as end in themselves" (Kant, 1998, p. 41). From this point of view, the right to determine the circumstances of one's own life is a matter of dignity.

Kant considers rights and responsibilities of people as absolute or unconditional and does not admit any exceptions whatsoever in this regard. He contends that the principle of justice or fairness must be the same for everyone. This leads to the rule that what is fair for one must be fair for all. One corollary of this rule is that one ought to not only do what is morally right, but should also do it for the right reason. However, the rightness of an action is not determined by its consequences. In other words, people are not morally called on to seek the best overall consequences by their actions, but rather to perform those actions that accord with a moral duty - the fundamental demand that they should treat each other, 
and themselves, in a manner that is consistent with human dignity and worth (Kant, 1998, pp. 19, 43). Here, Kant aims to show how the principle of dignity can be achieved in social life by reference to three distinct but interrelated qualities of acts: (1) in terms of their degree of universality (act such that your maxim could become universal law); (2) in terms of their purpose or "end" (act such that all human beings are respected as ends in themselves); and (3) in terms of their connection with the complete social and political systems (act such that your maxim could be law in "the kingdom of ends") (Kant, 1998, pp. 38-41).

Having said this, from a Kantian point of view, the justification of authorities' intervention in hungers strikes can be objected, as it violates the notion of human autonomy and dignity. First and foremost, it is an act that uses other human beings as a means to achieve its own goals. Thus it violates the basic premise of Kantian moral position: all human beings are "ends in themselves", who have "dignity" or "intrinsic value" that is "above all price". This means that strikers are denied the capacity of being endowed with free will, even though they deserve to be treated with respect. The same act also denies the strikers' capacity to evaluate, judge and aim as autonomous agents, a capacity which has a worth in itself. Remembering that autonomy is an indispensable precondition of dignity, we can conclude that authorities deny the dignity of strikers by terminating their autonomy. This shows that authorities do not approve the condition that strikers are "rational" human beings, who must be respected. Needless to say, only those who are respected are granted the quality of dignity.

In this context, we can remember that the traditional prison life before the introduction of F-type had a meaning and worth for prisoners. Nevertheless, the prison is not essentially a "good" to them because the good of prison is outweighed by its bad. To put it simply, they are incarcerated, and this fact does not change with the change of the form of prison. Therefore, the worth of prison for them cannot be measured solely by its worth for the strikers. This raises a new issue in regard to the notion of dignity. We have seen that authorities treat strikers as a mere means for their ends. But is it also immoral for prisoners to treat themselves as a mere means for their own ends? Do the strikers grant dignity to themselves in their struggle? It seems to be difficult to affirm their acts as self-dignifying because they use themselves as a means for their own purposes. What prisoners did assert when they aimed at their own death was to eliminate the denial of their existence. So they ought not to pursue "death strike" aiming to finish their existence. It is this paradox in their act that does not allow us to call their act self-dignifying in a Kantian sense. We must also emphasize that Kant's conceptualization of dignity forbids lessening one's rational agency to gain some instrumental value. ${ }^{4}$ Yet "death strikes" are exactly lessening one's rational agency without which one cannot have dignity. Perhaps the self-imposed negation of rational agency is a direct outcome of the prison life, as the prison seen as Panopticon is against the rational nature of human beings, who need to develop their capacity to be normatively self-legislating, the capacity for participation in moral life. The capacity to self-legislation is crucial to the moral status because through it, a rational being can be an end in itself, because only through it is it possible to be a legislative member in the realm of ends. Thus morality and humanity, so far as it is capable of morality, alone have dignity. Human nature is necessarily grounded in autonomy. Autonomy is the source of the dignity of every rational human being (Kant, 1998, pp. 42-43). Therefore, the denouncement of one's autonomy under panoptical systems is identical with denouncement of one's moral freedom or moral capacity that produces conclusive "rational" premises for formulating and understanding behavioral rules and fulfilling requirements of a common human life. 


\section{Reconsidering the Meaning of Hunger Strikes}

Hunger strikes are typically associated with ex-communicative and strategic acts of protest particularly in the context of a lengthy political struggle (Wee, 2004, pp. 21-65). The pursuit of changing an antagonistic political configuration is often associated with a heroic journey. A hunger strike is one such journey. In this journey, hunger strikers combine passion, rage, and self-sacrifice with reason and intellect. The passion that motivates the strikers underpins the initially perceived altruism and justice (Nussbaum, 1996, p. 37). Because of this, strikers are capable of risking their life for a social and political causesomething most of us have difficulty in understanding. Yet a hunger strike is a meaningful human act; that is, it is not an act without social significance. Because it has a social and political meaning (in other words, justice) attached to it, it is possible for us to comprehend it. Here we offer a possible understanding of one of the meanings of hunger strikes in Turkey. We must try to move beyond the strong wills of the hunger strikers and focus on the question of what their actions signify.

We begin with the fact that when one commits oneself to a hunger strike, one is already convinced that this is an act of "good". Nevertheless, the perception of good almost always has its roots in a moral organization of human life and hence, it has a social dimension. In other words, a hunger strike is a moral act as much as a political act. The good associated with this act gives the person a sense of purpose or rather a "calling". The question may be posed: what is the "calling" in the hunger strike in reference to the F-type prisons? By remembering the forced transfer of some inmates out of their accustomed space into an unfamiliar surrounding, one conjectures that the "calling" may have something to do with the need to be in control of one's own life conditions. But is this the primary reason or are there other reasons? For example, did they receive an order from organizational leaders? Did they see it as part of their ideological and political struggles against their "oppressors"? Or did they see it as primarily a voluntary act that had its roots in the "calling" we defined above? These questions appear to be crucial if we are to understand what led these people to choose death over life. It may be possible to assert that all of the above factors may have contributed to some extent, but it is also possible that the action was taken due to the "calling". Simply put, although there is not one single precise underlying meaning that can explain the hunger strikes, the perception may be that it is based on the loss of control of and over one's life conditions as referred to above.

From this point of view, all hunger strikes can be seen as the means to maximize the chance of regaining control. If we would like to look closer at what this "regaining of control" means we can see that it is an attempt to reaffirm one's own being through the negation of a particular other. The latter (in other words, in our case the Panopticon jail system as a technology of power and discipline) has already negated the being of the hunger striker. Thus, the hunger striker first and foremost negates the negating other in order to acquire his/her being back. What is interesting and perplexing is the method of negation that he/she uses. The hunger striker negates his or her life in order to reaffirm his or her being negated now by the Panopticon technology of the F-type prison. In other words, the hunger strike here is a conscious and direct denial of one of the most fundamental human rights by the person, that is, "the right to live". This is definitely what it seems he/she is doing. Yet when we have a closer look at it again, we can see that he/she is actually denying his/her being reduced to a biological organism without human essence. In this sense he/she is just denying this very reduction and not his/her human right because 
he/she aims to put an end to his/her physical existence, thus stripping his/her controller's opportunity to control. Moreover and perhaps more importantly, by using the method of a slow process of dying over suicide he/she is seemingly trying to send out a message to all citizens, who now find themselves in a difficult situation of choice (Williams, 2001, p. 287). Citizens are all now asked by the hunger striker to negate either his/her action or the F-type prison. If they choose to remain silent or fail to support him/her, the hunger striker can turn to all of them and say: "You are denying your responsibility because you are not aware of the true meaning of being a citizen, which is having a moral character requiring the right to have control over one's actions and interactions. So I am not denying my fundamental human right, I am just demanding to get it back and make a recourse to the right to die. Perhaps you can now understand what it means to be a citizen. And I am dying for justice. I am a martyr of liberty of conscience". The hunger striker gains a certain type of empowerment from taking on the role of the martyr. A martyr is viewed as a hero and voluntarily suffers death as the penalty for refusing to renounce his/her values and principles. Suffering and death invoke responses from the other members of the political community. The response shall most probably be a compassionate one. In other words, a feeling of compassion is aroused as a response to what would commonly be judged to be done only by a hero. As Kierkegaard suitably explains it:

When one person is the tyrant, the mass is not completely secularized, but "the mass" wants to by tyrant, then worldliness is completely universal, and then only the martyr can be the ruler]. No doubt there is an infinite difference between a tyrant and a martyr; yet they have one thing in common: the power to constrain. The tyrant, with a craving for power, constraints by force; the martyr, personally unconditionally obedient to God, constrains by his own sufferings. Then the tyrant dies, and his rule is over; the martyr dies, and his rule begins. (Kierkegaard, 1998, pp. 281-282)

In a way, the strikers in the prisons stated their "calling" by their deaths: "We can die, we can sacrifice our bodies, but we cannot let any authority touch our lives because we are powerful enough to resist all your ignorance of us as citizens". Thus the hunger strikes that caused the death of 120 people were in fact for the common good and for the right to live.

\section{Hunger Strikes As Struggles for Recognition}

Based on what has been stated up until now, it is possible to suggest that hunger strikes are the confirmation of a certain morality. They do not mean the negation of life but, on the very contrary, the affirmation of it. Human life rests upon ideas and values that provide meaning for people making up a society. The ideas and values are part of social, cultural and political environments and help people to identify themselves in the world. Acceptance of these ideas and values in the process of identity formation of individuals varies from person to person. This is because each individual may experience the very same social, cultural and political environment in diverse ways. Although one's position in the environment may create an objective foundation for the choice of certain values and ideas over others the actual personality is always a product of interaction between the objective conditions and their subjective interpretations. Human individuals have the capacity to give a new meaning to an already meaningful world. In other words, 
the objective conditions that are already meaningful in themselves can be reinterpreted in a completely different way and given a completely new meaning by the active agency of individuals. By being active in the world individuals appropriate and form certain values and ideas for themselves and hence provide their life with a vocation.

Without considering the active/subjective dimension of the personalities of hunger strikers we contend that it is not possible to understand how they impose themselves upon the citizens of their political community. Hegel's reflection on the "Master Servant" relation in his Phenomenology of Spirit (Hegel, 1979, p. 115, Section 190) can help us to see how this occurs. For Hegel, human beings are not only conscious beings but also selfconscious beings. To be conscious is to know that one is dependent on the world. This is a precondition of having self-consciousness which is considering the world as dependent on the self. In other words, human beings can understand the external existence of the world for them yet they make sense of that objective entity by attaching a meaning to it. Giving a meaning to the world is the projection of the self on to the world. Thus, the world is to a certain extent perceived by the human subject as the reflection of his/her consciousness. This leads him/her to search for another self-conscious being from whom he/she will attempt to get his/her affirmation. Yet this is a contradictory relationship to begin with, as the other will attempt to do the same on his/her part. So there emerges a will on each side to subordinate the other so that one is eventually affirmed in his/her projecting of himself/herself on the world. Here the will to subordinate is essentially to make the other recognize one's self as a position of power/domination over the other. But the other insists on asking the recognition of his/her own power/domination, which inevitably leads to a deadly struggle between the two. The struggle does result in one side being the master (who is allegedly free) and the other side being the servant (who is rendered un-free). The master now is recognized by the servant as the authority allowing him/her to feel acknowledged. However, the master does not recognize the servant and thus the servant's self-consciousness is left unacknowledged (Hegel, 1979, p. 116, Section 191). First, the problem for the master is that he/she can never know for sure whether the servant affirms him/her because the master has not recognized him/her in the first place. Second, because of the servant's being un-free his/her actions cannot truly represent his/her selfconsciousness.

Returning to the hunger strikes, we can refer to the F-type prisons as a claim to authority over prisoners, aiming to subordinate them to a particular self-consciousness without granting them any recognition. The prisoners' self-consciousness is denied by taking away their freedom and rights. The main objective for using the F-type prisons is to stop communication and relationships among inmates. If once this privilege is removed and inmates are forcefully led to the recognition of the prison administration, can one be sure whether the prisoners will have any inclination to affirm the authority? As we have already explained above, the prisoners did not only affirm the authority but they didn't even wish to recognize the new arrangement. So they denied their master by denying their servitude forcing the master to be openly oppressive. In other words, by denying that they can be rendered servants they made the master reveal its true identity. Yet at the same time their denial of themselves revealed their true self-consciousness or identity, which appears to be vigilant to any kind of denial of their right to have control over their life. Given the deadly struggle between the two, it is not surprising that the un-free prisoners have bravely "faced death in the eye". With the utilization of Hegelian notions, their courageous decision to put an end to their lives was the "negation of negation", which was a movement toward their 
self-recognition and self-determination. This was constitutive of a new morality in regard to being "inside". The prisoners arrived at new morality by acting as moral subjects because they had the boldness to deny another moral subject.

In Nietzsche's philosophy the moral relationship between the inmates and the prison authority refers to the moral relationship between masters and slaves. In The Genealogy of Morals, Nietzsche describes slave morality as the morality of the suffering and oppressed who identify their rulers as "evil" and therefore conceive themselves as "good". Nietzsche points out that slave morality is nothing more than another expression of will to power. For him, will to power is the basic drive of human beings for freedom from, and domination over, other wills (Nietzsche, 1968, p. 298). "Will to power" refers to the human disposition through which one realizes oneself according to what one needs for having a fulfilled or rather moral life. Nietzsche considers that the people, who are solid, firm, persuasive, convincing and resolute, create their own values in life. The genealogy of history has persuaded Nietzsche that the will to power has been turned against the moral orders separating individuals as nobles and slaves. In time, new moral orders have been formed, which favored the weak, the suffering, the sick, the criminal, and the incompetent (Nietzsche, 1969: I, Section 11, pp. 475-476). The formations of these moral orders were a direct result of the experiences of oppression and frustration of slaves who first turned their own will to power against themselves. The frustration always played an important role for legitimizing the creation of a new type of morality. In Nietzsche's terminology, the frustration is called resentment. Resentment, associated with the reaction to the will to power of others, was a stimulating state of being. Those whose will to power were denied would be inclined towards finding a way of expressing their resentment. When their will to power was not allowed to be expressed, they turned upon themselves to express their resentment. Slaves who were enrolled into this dilemma without their conscious choice have come to accept a particular type of moral responsibility, lacking in their social environment. That was not essentially something good in itself but it was a "good" because it represented the free expression of will to power taken away by domination and oppression.

Using Nietzsche's notions we can argue that the novel morality of hunger strikers in Turkey at times appears to be a reaction, at other times an experience of frustration but at all times it expresses the desire to put an end to domination and oppression and a will to power denied to them (Williams, 2001, p. 287). For those hunger strikers the F-type prison which allegedly was introduced to be a "good" by the authority was an "evil". What was evil for the authority was a good for those strikers. In the self-consciousness of the strikers expressed by their deaths, the evil of the authority stemmed from its denial of granting justice to them. That's why their struggle can also be characterized as a struggle against social injustice. Their struggle involved a demand for equality in terms of having the right to be recognized as self-conscious individuals (Wee, 2004, p. 2170). It was this demand that was constitutive of the new morality and new justice.

We can emphasize that justice is not only an essential basis for the development of a sense of self, but also for the establishment of good citizenship. Good citizenship requires having social norms, respecting the others as equal persons capable of acting responsibly, autonomously and rationally. Being respected by others as an autonomous person promotes conditions for justice through the removal of existing positive oppressions and of barriers in the pursuit of a good life. To be denied moral respect is actually to experience both a deformation of one's relation to one's self and a wound to one's own existence. A citizenship comprising such individuals cannot have justice. 
There is a close connection between the recognition and substantive understanding of the good. According to Aristotle, every human being tends towards some end, that is, good life. The aspiration toward good life is a reality of human nature. It exists in people necessarily. Aristotle tries to detect or determine what the good life is really based on, this supreme good toward which people necessarily aim. Aristotle thinks it is the supreme good or sovereign good that is state or activity that makes the life of citizens better (Aristotle, 1976, p. 251 or 1153b25). It represents doing well and living well. Aristotle believes that it is community life that makes the life of citizens better. Aristotle does not tell us that we ought to tend toward community life - the aspiration toward community life is a fact of human nature. It exists in people necessarily. The aim toward living a communal life exists as a means for the perfect fulfillment of human nature. Here Aristotle uses the word human nature more in a metaphysical context. He thinks that each human being possesses a reason that determines them in its species, and tendencies and inclinations. This reason exists in people for the necessity of pursuing the good life (eudaemonia) (Aristotle, 1976, pp. 6364 or 1094a1). For Aristotle, eudaemonia is where people have attained complete fulfillment of their aspirations and achieved happiness in conformity with ends proper to their social nature.

The Aristotelian conception of good life, or of eudaemonia, is not a single activity or hedonistic state that one seeks, but it is a social activity that expresses living well and doing well in community life. Thus, eudaemonia is constituted of activities that necessarily include social interaction and relationships of the political community of citizens. For this reason, Aristotle asserts that people are "by nature political animals". He believes that human life flourishes best within the integrated life of the political community (Aristotle, 1992, p. 59 or 12153a1-7). Therefore, social interaction and relationships contain not only elements for one orienting oneself $v i s-\grave{a}$-vis self-realization, but also for the existing social features that one understands himself/herself as a connected being that can interactively accomplish a good life for all citizens. Therefore, humans have a natural inclination to live in a political community in which their good is accomplished only in unity. This becomes clear when we reflect on their purpose for good life, which is not purely individual, but rather communitarian. Simply put, people are not happy alone and they recognize the value of living together.

We can therefore state that those prisoners protesting and resisting their placement in isolated cells were actually showing a basic orientation for a good of life in their political community. Here, the good life was their inclination to live together just as in open dormitories. An individual prison cell, which denies all contact between the prisoners, thus destroys aspirations for having the good life. Therefore, the inmate's innate purpose is not only directed towards the good of the whole but also proceeds against the evil of an absolute separation from others.

To have a good life and ethically justify it involves showing that the person can act in his/her best capacity ethically in diverse encounters in life. The best act is always yet to come. That is to say, each encounter can always be ethically approached from within the already existing good life accomplished in the political community; but it can also be reinterpreted and given a new meaning for all concerned in the name of a better life. It is that latter possibility that makes us consider and question our moral responsibilities with a duty to improve conditions in our citizenship structures and practices. This also means that there is some innate potential for being considerate of others more than our very own selves. That is, we have the potential to be altruistic. From this vantage point, we may 
finally conclude that the hunger strikers aimed at a better organization of the life of citizens and took an altruistic path toward their community. Their communitarian reasoning transformed the meaning of death from a negative connotation to a completely positive human act. It reminded all citizens that a dignified human being can choose to die to prove to the rest that what makes us individual citizens is dignity.

\section{Conclusion}

In this paper, we argued that hunger strikes can be first considered as voluntary fasting undertaken as a means of civil disobedience against an injustice within the context of citizenship. Second, they can be understood as examples of non-violent political acts and are inevitably part of citizenship politics because they express a commitment to achieving one's goals through non-aggressive means for the common good of all citizens. Third, they can be considered examples of martyrdom/heroism because hunger strikers altruistically risk their life for a public cause. Fourth, hunger strikes can be seen as political acts of communication with fellow citizens as well as a method of negotiation because in the strikers' actions there is always a message sent not only to their opponents but to all citizens (Williams, 2001, p. 287). Fifth, they can be seen as expressions of selfdetermination for having control over and for one's life in such a way that they feel contented about their existence. This requires strength and passion. Sixth, hunger strikes can be conceptualized as the struggle for transforming the configuration of structures and practices of citizenship about which one is passionately concerned. Seventh, hunger strikes can be conceptualized as struggles for recognition in a relationship between two subjects, in which one subject subordinates the other.

\section{Notes}

${ }^{1}$ The information provided in this section is taken from the web page of the Turkish Ministry of Justice (http://www.cte.adalet.gov.tr).

2 According to the definition provided by Article 1 of the Anti-Terror Law numbered 3713 dating from 1991 and amended in 2003 as an adaptation for the European Union, terror is described as the following. The use of any method involving the characteristics of violence, force, pressure, intimidation, discouragement, oppression or threats that aims to alter the qualities of the republic, that is: political, lawful, secular, social and economic order, and the indivisibility of state with its people and country; or people or groups of people who act/acts with aims to jeopardize the existence of the republic and state, to weaken or to take over or to destroy state authority, human rights and freedoms, or to damage the general order of internal and external security of the state. Any of the above are considered as criminal acts/actions.

${ }^{3}$ For more detailed information about the rights of prisoners, see the Appendix.

${ }^{4}$ Within particular context, Kant explicitly argues against taking one's life. He says: "First as regards the concepts of necessary duty to oneself, someone who has suicide in mind will ask himself whether his action can be consistent with the idea of humanity as an end in itself. If he destroys himself in order to escape from a trying condition, he makes use of his person merely as a means so as to maintain a tolerable condition up to the end of life. A human being, however, is not a thing, and hence is not something to be used merely as a means; he must in all his actions always be regarded as an end in himself. I cannot, therefore, dispose of human being in my own person by maiming, damaging, or killing him. (I must here pass over closer determination of this principle that would prevent misinterpretation, for example, as to the amputation of the limbs in order to preserve myself, as to putting my life in danger in order to preserve my life, and so forth; that belongs to moral proper)" (Kant, 1998, p. 38. 


\section{References}

Aristotle (1976) Ethics, J.A.K. Thompson (Trans.) (London: Penguin Books).

Aristotle (1992) Politics, T.A. Sinclair (Trans.) (London: Penguin Books).

Bentham, J. (1995) The Panopticon Writings, in: M. Bozovic (Ed.) (London: Verso).

European Committee for the Prevention of Torture and Inhuman or Degrading Treatment or Punishment (CPT) (1999) Report to the Turkish government on the visit to Turkey carried out from 5 to 17 October 1997 , available at http://www.cpt.coe.int/en/docspublic.htm.

Foucault, M. (1979) Discipline and Punish: The Birth of the Prison (London: Penguin Books).

Hegel, G. W. H. (1979) Phenomenology of Spirit, A.V. Miller (Trans.) (Oxford: Oxford University Press).

Hobbes, T. (1994) Leviathan (London: Everyman).

Kant, I. (1998) Groundwork of the Metaphysics of Morals, M. Gregor (Trans.) (Cambridge: Cambridge University Press).

Kierkegaard, S. (1998) The Point of View: The Point of View v. 22 (Kierkegaards Writings) H.V. Hong \& E.H. Hong (Trans.) (Princeton: Princeton University Press).

Koçan, G. \& Öncü, A. (2004) Citizen Alevi in Turkey: beyond confirmation and denial, Journal of Historical Sociology, 17(4), pp. 464-490.

Koçan, G. \& Öncü, A. (2005) Political identity and citizenship politics: nationalism and cosmopolitanism in the Bergama Movement in Turkey, in: H. G. Sicakkan \& Y. Lithman (Eds) Changing the Basis of Citizenship in the Modern State (New York: Edwin Mellen Press).

Lippke, R. L. (2002) Toward a theory of prisoner's rights, Ratio Juris, 15(2), pp. 122-145.

Locke, J (1993) Two Treaties of Government (London: Everyman).

Nietzsche, F. (1968) The Will to Power, W. Kaufmann \& R.J. Hollingdale (Trans.), in: W. Kaufmann (Ed.) (New York: Random House).

Nietzsche, F. (1969) On the Genealogy of Morals, in Basic Writings of Nietzsche, W. Kaufmann (Trans., Ed.) (New York: Random House).

Nietzsche, F. (1974) The Gay Science, W. Kaufmann (Trans.) (New York: Vintage Books).

Nussbaum, M. (1990) Love's Knowledge (New York: Oxford University Press).

Nussbaum, M. (1996) Compassion: the basic social emotion, Social Philosophy and Policy, 13(1), pp. 27-58.

Öncü, A. (2003a) Political identity as structure and agency: an institutional analysis of the organization of engineers in Turkey, International Review of Sociology, 13(2), pp. 303-320.

Öncü, A. (2003b) Dictatorship plus hegemony: a Gramscian analysis of the Turkish state, Science and Society, 67(3), pp. 303-328.

Öncï, A. (2003c) A Sociological Inquiry into the History of the Union of Turkish Chambers of Engineers and Architects: Engineers and the State, Mellen Studies in Sociology, Vol. 37 (New York: Edwin Mellen Press).

Rousseau, J. J. (1988) Social Contract in Rousseau's Political Writings, A. Ritter \& J.C. Bondanella (Trans., Ed.) (New York: W.W. Norton).

Weber, M. (1947) The Theory of Social and Economic Organization, T. Parsons (Trans.) (London: Free Press).

Wee, L. (2004) Extreme communicative acts and the boosting of illocutionary force, Journal of Pragmatics, 36, pp. 2161-2178.

Williams, J. (2001) Hunger-strikes: a prisoner's right or "wicked folly", The Howard Journal, 40(3), pp. 285-296. 


\section{Appendix}

Table 1. Types and capacity of prisons

\begin{tabular}{|c|c|c|c|c|}
\hline No & Type & Unit & Project capacity & Total \\
\hline 1 & $\mathrm{~A}$ & 52 & 24 & 1612 \\
\hline 2 & A1 & 49 & 24 & 1376 \\
\hline 3 & A2 & 23 & 40 & 968 \\
\hline 4 & A3 & 35 & 60 & 2546 \\
\hline 5 & B & 21 & 130 & 1411 \\
\hline 6 & $\mathrm{C}(*)$ & 8 & 300 & 1695 \\
\hline 7 & $\mathrm{E}(*)$ & 45 & 600 & 21,082 \\
\hline 8 & $\mathrm{~F}$ & 11 & 368 & 4212 \\
\hline 9 & K1 & 126 & 42 & 5351 \\
\hline 10 & $\mathrm{~K} 2$ & 38 & 60 & 2326 \\
\hline 11 & $\begin{array}{l}\text { Province prisons not constructed on certain } \\
\text { type project }\end{array}$ & 20 & Varied & 8968 \\
\hline 12 & $\mathrm{M}(*)$ & 24 & 350 & 6439 \\
\hline 13 & $\mathrm{H}$ & 6 & 500 & 2480 \\
\hline 14 & $\mathrm{D}$ & 1 & 750 & 750 \\
\hline 15 & $\begin{array}{l}\text { District prisons not constructed on certain } \\
\text { type of project }\end{array}$ & 12 & Varied & 532 \\
\hline 16 & Rental closed prisons & 6 & Varied & 168 \\
\hline 17 & $\begin{array}{l}\text { Open prisons governed by a separate } \\
\text { governor not affiliated to a closed } \\
\text { prison governor not affiliated to a } \\
\text { closed prison governor }\end{array}$ & 20 & Varied & 5335 \\
\hline 18 & $\begin{array}{l}\text { Open prisons under the directorate of } \\
\text { closed prisons }\end{array}$ & 19 & Varied & 1911 \\
\hline 19 & Juvenile reformatories & 3 & Varied & 600 \\
\hline 20 & Women and juvenile institution & 1 & 480 & 480 \\
\hline 21 & Women prison & 1 & & 400 \\
\hline 22 & Juvenile prison & 1 & & 400 \\
\hline 23 & Juvenile institution & 1 & 60 & 60 \\
\hline Total & & $503(*)$ & & 70,994 \\
\hline
\end{tabular}

Source: Ministry of Justice, http://www.cte.adalet.gov.tr/. 
The Morality of Living and Dying 367

Table 2. Convicted and remand prisoners according to years by the annual total number

\begin{tabular}{|c|c|c|c|c|c|c|c|}
\hline \multirow[b]{2}{*}{ Years } & \multicolumn{3}{|c|}{ Convicted prisoners } & \multicolumn{3}{|c|}{ Remand prisoners } & \multirow[b]{2}{*}{ Gen. total } \\
\hline & $\begin{array}{c}\text { Common } \\
\text { crimes }\end{array}$ & $\begin{array}{l}\text { Terror } \\
\text { crimes }\end{array}$ & Total & $\begin{array}{l}\text { Common } \\
\text { crimes }\end{array}$ & $\begin{array}{l}\text { Terror } \\
\text { crimes }\end{array}$ & Total & \\
\hline 1970 & 30,119 & - & 30,119 & 26,392 & - & 26,392 & 56,511 \\
\hline 1971 & 33,416 & - & 33,416 & 28,047 & - & 28,047 & 63,458 \\
\hline 1972 & 36,140 & - & 36,140 & 28,749 & - & 28,749 & 64,889 \\
\hline 1973 & 33,722 & - & 33,722 & 27,246 & - & 27,246 & 60,968 \\
\hline 1974 & 5442 & - & 5442 & 19,418 & - & 19,418 & 24,860 \\
\hline 1975 & 14,276 & - & 14,276 & 23,340 & - & 23,340 & 37,616 \\
\hline 1976 & 19,881 & - & 19,881 & 24,450 & - & 24,450 & 44,331 \\
\hline 1977 & 22,632 & - & 22,632 & 27,752 & - & 27,752 & 50,384 \\
\hline 1978 & 25,212 & - & 25,212 & 29,430 & - & 29,430 & 54,642 \\
\hline 1979 & 22,417 & - & 22,417 & 30,236 & - & 30,236 & 52,653 \\
\hline 1980 & 31,241 & - & 31,241 & 38,931 & - & 38,931 & 70,172 \\
\hline 1981 & 42,446 & - & 42,446 & 37,340 & - & 37,340 & 79,786 \\
\hline 1982 & 44,650 & - & 44,650 & 33,551 & - & 33,551 & 78,201 \\
\hline 1983 & 45,144 & - & 45,144 & 31,114 & - & 31,114 & 76,258 \\
\hline 1984 & 44,208 & 2162 & 46,370 & 26,100 & 594 & 26,694 & 73,064 \\
\hline 1985 & 42,693 & 2695 & 45,388 & 25,050 & 792 & 25,842 & 71,230 \\
\hline 1986 & 29,157 & 1629 & 30,786 & 20,942 & 422 & 21,364 & 52,150 \\
\hline 1987 & 29,134 & 2181 & 31,315 & 18,705 & 779 & 19,484 & 50,799 \\
\hline 1988 & 30,982 & 2096 & 33,078 & 16,895 & 1697 & 18,592 & 51,670 \\
\hline 1989 & 27,600 & 1807 & 29,407 & 15,941 & 1756 & 17,597 & 47,104 \\
\hline 1990 & 27,731 & 1642 & 29,373 & 14,488 & 1745 & 16,233 & 45,606 \\
\hline 1991 & 10,652 & 395 & 11,047 & 14,760 & 1044 & 15,804 & 26,851 \\
\hline 1992 & 12,301 & 522 & 12,823 & 15,597 & 3062 & 18,659 & 31,482 \\
\hline 1993 & 14,300 & 847 & 15,147 & 14,681 & 4977 & 19,658 & 34,805 \\
\hline 1994 & 15,787 & 1094 & 16,881 & 15,638 & 6412 & 22,050 & 38,931 \\
\hline 1995 & 20,371 & 1637 & 22,008 & 17,058 & 7025 & 24,083 & 46,091 \\
\hline 1996 & 24,651 & 2328 & 26,979 & 17,697 & 6207 & 23,904 & 50,883 \\
\hline 1997 & 32,155 & 4179 & 36,334 & 19,346 & 4926 & 24,272 & 60,606 \\
\hline 1998 & 31,647 & 4239 & 35,886 & 19,670 & 4835 & 24,505 & 60,391 \\
\hline 1999 & 37,986 & 6145 & 44,131 & 19,953 & 3497 & 23,450 & 67581 \\
\hline 2000 & 20,378 & 4467 & 24,855 & 20,467 & 4190 & 24,657 & 49,512 \\
\hline 2001 & 22,425 & 5116 & 27,541 & 24,886 & 3182 & 28,068 & 55,609 \\
\hline 2002 & 25,514 & 5123 & 30,637 & 25,928 & 2622 & 28,550 & 59,187 \\
\hline 2003 & 28,554 & 4161 & 32,715 & 29,605 & 1976 & 31,581 & 64,296 \\
\hline 2004 & 23,840 & 2170 & 26,010 & 30,302 & 1618 & 31,920 & 57,930 \\
\hline
\end{tabular}

Source: Ministry of Justice, http://www.cte.adalet.gov.tr/. 
Table 3. Prisoners according to the number of admissions and release in March 2004

\begin{tabular}{|c|c|c|c|c|c|c|c|c|c|c|c|c|c|}
\hline & \multicolumn{4}{|c|}{ Convicted prisoners } & \multicolumn{4}{|c|}{$\begin{array}{l}\text { Convicted but not yet finally } \\
\text { sentenced }\end{array}$} & \multicolumn{4}{|c|}{ Remand prisoners } & \multirow{3}{*}{ Total } \\
\hline & \multicolumn{2}{|c|}{ Male } & \multicolumn{2}{|c|}{ Female } & \multicolumn{2}{|c|}{ Male } & \multicolumn{2}{|c|}{ Female } & \multicolumn{2}{|c|}{ Male } & \multicolumn{2}{|c|}{ Female } & \\
\hline & Adult & Child & Adult & Child & Adult & Child & Adult & Child & Adult & Child & Adult & Child & \\
\hline Admission & 12,392 & 90 & 467 & 1 & 899 & 28 & 37 & 0 & 8075 & 607 & 375 & 13 & 22,984 \\
\hline Release & 11,376 & 89 & 397 & 0 & 843 & 32 & 38 & 3 & 7607 & 530 & 327 & 8 & 21,250 \\
\hline
\end{tabular}

Adult: a prisoner over 18 years old.

Child: a prisoner under 18 years old but not younger than 12 years old.

Source: Ministry of Justice, http://www.cte.adalet.gov.tr/. 
Table 4. Convicted and remand prisoners according to their education levels

\begin{tabular}{|c|c|c|c|c|c|c|c|c|c|c|c|c|c|}
\hline \multirow[b]{3}{*}{ Education level } & \multicolumn{4}{|c|}{$\begin{array}{l}\text { Convicted prisoners (sentenced to } \\
\text { final judgment) }\end{array}$} & \multicolumn{4}{|c|}{$\begin{array}{l}\text { Convicted but not yet finally } \\
\text { sentenced }\end{array}$} & \multicolumn{4}{|c|}{ Remand priso.ners } & \multirow[b]{3}{*}{ Total } \\
\hline & \multicolumn{2}{|c|}{ Male } & \multicolumn{2}{|c|}{ Female } & \multicolumn{2}{|c|}{ Male } & \multicolumn{2}{|c|}{ Female } & \multicolumn{2}{|c|}{ Male } & \multicolumn{2}{|c|}{ Female } & \\
\hline & Adult & Child & Adult & Child & Adult & Child & Adult & Child & Adult & Child & Adult & Child & \\
\hline Uneducated & 671 & 32 & 120 & 2 & 149 & 21 & 28 & & 867 & 187 & 176 & 10 & 2263 \\
\hline Literate & 1432 & 31 & 89 & & 225 & 25 & 16 & & 1636 & 217 & 71 & 4 & 3746 \\
\hline Elementary cont. & 539 & 22 & 16 & & 131 & 9 & 3 & & 140 & 54 & 8 & 1 & 923 \\
\hline Elementary & 17,505 & 90 & 404 & & 3498 & 89 & 138 & 3 & 11,249 & 793 & 380 & 6 & 34,155 \\
\hline Middle school cont. & 1247 & 106 & 95 & 2 & 268 & 11 & 8 & & 452 & 55 & 15 & & 2259 \\
\hline Middle school & 4592 & 27 & 103 & & 1001 & 47 & 17 & 1 & 4363 & 307 & 92 & 6 & 10,556 \\
\hline High school cont. & 669 & 90 & 23 & & 159 & 17 & 3 & 1 & 356 & 68 & 12 & 1 & 1399 \\
\hline High school & 4525 & 3 & 159 & 1 & 802 & 22 & 24 & & 3214 & 43 & 12 & 2 & 8807 \\
\hline College cont. & 223 & & 7 & & 52 & & 3 & & 285 & & 3 & & 573 \\
\hline College & 750 & & 36 & & 98 & & 13 & & 442 & & 30 & & 1369 \\
\hline Doctorate cont. & 1 & & & & 1 & & & & 3 & & & & 5 \\
\hline Doctorate & 2 & & & & & & & & 1 & & & & 3 \\
\hline Other & 927 & & & & & & & & 520 & 42 & 225 & & 1714 \\
\hline Total & 33,083 & 401 & 1052 & 5 & 6384 & 241 & 253 & 5 & 23,528 & 1766 & 1024 & 30 & 67,772 \\
\hline
\end{tabular}

Adult: a prisoner over 18 years old.

Child: a prisoner under 18 years old but not younger than 12 years old.

Source: Ministry of Justice, http://www.cte.adalet.gov.tr/. 
Table 5. Convicts according to the type of crimes

\begin{tabular}{lccrr}
\hline & $\begin{array}{c}\text { Remand } \\
\text { prisoners }\end{array}$ & $\begin{array}{c}\text { Convicted but } \\
\text { not yet finally } \\
\text { sentenced }\end{array}$ & $\begin{array}{c}\text { Convicted } \\
\text { prisoners }\end{array}$ & Total \\
\hline Crime division & 25,394 & 4282 & 31,618 & 61,294 \\
$\begin{array}{l}\text { Funmon crimes } \\
\text { right wing terror crimes }\end{array}$ & 622 & 43 & 498 & 1163 \\
$\begin{array}{l}\text { Marxist-Leninist or separatist } \\
\text { left wing terror crimes }\end{array}$ & 978 & 194 & 3225 & 4397 \\
$\begin{array}{l}\text { Terror crimes (confessor or repentant) } \\
\text { Profit oriented criminal organization }\end{array}$ & 56 & 14 & 179 & 249 \\
Total & 28,101 & 4621 & 310 & 1449 \\
\hline
\end{tabular}

Source: Ministry of Justice, http://www.cte.adalet.gov.tr/. 
Table 6. Convicted and remand prisoners according to length of sentence

\begin{tabular}{|c|c|c|c|c|c|c|c|c|c|c|c|c|c|c|}
\hline \multicolumn{2}{|l|}{ Penalty duration } & \multicolumn{4}{|c|}{$\begin{array}{l}\text { Convicted prisoners (sentenced to } \\
\text { final judgment) }\end{array}$} & \multicolumn{4}{|c|}{$\begin{array}{l}\text { Convicted but not yet finally } \\
\text { sentenced }\end{array}$} & \multicolumn{4}{|c|}{ Remand prisoners } & \multirow{3}{*}{ General total } \\
\hline & & \multicolumn{2}{|c|}{ Male } & \multicolumn{2}{|c|}{ Female } & \multicolumn{2}{|c|}{ Male } & \multicolumn{2}{|c|}{ Female } & \multicolumn{2}{|c|}{ Male } & \multicolumn{2}{|c|}{ Female } & \\
\hline Min. & Max. & Adult & Child & Adult & Child & Adult & Child & Adult & Child & Adult & Child & Adult & Child & \\
\hline 1 day & 1 month & 1401 & 1 & 65 & & 67 & & & & 6296 & 508 & 235 & 12 & 8585 \\
\hline 1 month & 3 month & 973 & 8 & 49 & & 86 & & 2 & & 5692 & 528 & 269 & 6 & 7613 \\
\hline 3 month & 6 month & 1145 & 1 & 25 & & 268 & 20 & 14 & & 4359 & 342 & 151 & 3 & 6328 \\
\hline 6 month & 1 year & 1800 & 9 & 41 & & 643 & 42 & 27 & 1 & 2749 & 212 & 110 & 4 & 5638 \\
\hline 1 year & 2 year & 3171 & 35 & 72 & 1 & 970 & 67 & 27 & 2 & 1852 & 98 & 54 & 5 & 6354 \\
\hline 2 year & 3 year & 2861 & 25 & 109 & & 644 & 19 & 23 & & 1042 & 17 & 18 & & 4758 \\
\hline 3 year & 5 year & 3643 & 89 & 131 & & 711 & 31 & 28 & & 580 & 1 & 13 & & 5227 \\
\hline 5 year & 10 year & 4968 & 137 & 120 & 1 & 906 & 48 & 42 & 1 & 296 & & & & 6519 \\
\hline 10 year & 15 year & 4900 & 70 & 221 & 3 & 782 & 10 & 33 & 1 & & & & & 6020 \\
\hline 15 year & 20 year & 2719 & 13 & 89 & & 555 & 2 & 23 & & & & & & 3401 \\
\hline 20 year & 25 year & 1459 & 9 & 27 & & 290 & 2 & 13 & & & & & & 1800 \\
\hline 25 year and over & 30 year & 1286 & 2 & 24 & & 249 & & 6 & & & & & & 1567 \\
\hline Life imprisonment & & 1809 & & 79 & & 213 & & 15 & & & & & & 2116 \\
\hline Other & & 948 & 2 & & & & & & & 662 & 60 & 174 & & 1846 \\
\hline Gen. total & & 33,083 & 401 & 1052 & 5 & 6384 & 241 & 253 & 5 & 23,528 & 1766 & 1024 & 30 & 67,772 \\
\hline $\begin{array}{l}\text { *Capital punishment } \\
\text { been implemented si } \\
\text { Source: Ministry Jus }\end{array}$ & $\begin{array}{l}\text { las been ab } \\
\text { ce then. } \\
\text { tice, http:// }\end{array}$ & $\begin{array}{l}\text { lished fro } \\
\text { www.cte.a }\end{array}$ & $\begin{array}{l}\text { TPC, e } \\
\text { alet.gov. }\end{array}$ & $\mathrm{r} /$. & d te & ne & Iditio & he & $\mathrm{a}$ def & rat & M & 4 as & $\mathrm{lp}$ & $\mathrm{t} \mathrm{t}$ \\
\hline
\end{tabular}


Table 7. Rights of prisoners in Turkey

In Turkey, all of the prisoners have the right to receive visitors on the occasions arranged by the prison administration according to visitor timetables. Exceptional visits may only be allowed with the written consent of the Chief Public Prosecutor or General Directorate of Prisons and Detention Houses according to the case. Prisoners also have the right to meet their defense counsels on occasions that are shown in the visiting timetable arranged by the prison administration. Exceptional meetings with the defense council are required a written consent of Chief Public Prosecutor.

All prisoners have the right to access various publications, listen to the radio, watch television and use the prison library. A wide variety of newspapers and publications not restricted by a court judgment may enter the prison with the approval of the administration. Inmates have the right to receive literacy courses and primary education while in prison. If they were students, prior to their entrance into prison, they are granted the right to continue their studies and attend examinations. All convicted (final sentence) prisoners who served a reasonable part of their total imprisonment and received good behavior conduct may be eligible for open prison at the end of each six month evaluation of their service. This decision is taken by the prison administrative board according to conditions and principles embodied in the circular put in force by the Ministry of Justice at the beginning of every year. Inmates have the right to request to be transferred to another closed prison assigned by the court. Convicted prisoners who served one fifth of their total prison sentence with good behavior conduct may be granted a short term leave from the prison for up to 10 days based on the recommendation of prison governor and the approval of the Chief Public Prosecutor. This may be granted in the case of any death of their close family relatives. Convicted prisoners in open prisons who have served one quarter of their total sentence and are seen to be successful at workshops may be granted a short term leave based on the recommendation of the prison governor and the approval of the Chief Public Prosecutor. In taking this decision the authorities, if there is little risk of flight by the prisoner, may grant up to 72 hours leave. All convicted prisoners have the right to be conditionally released if they did not receive any disciplinary punishment.

Prisoners are given disciplinary punishment by authorities according to the nature and seriousness of their action if they disturb the order in prison or when they violate relevant regulations. In such cases, a condemnation is issued by the prison governor, which comprises a warning to the prisoner about his/her wrong action, aiming to convince him/her not to repeat the action again. Prisoners may also receive a deprivation of visitor rights for up to three months as a disciplinary punishment issued by the prison disciplinary board. Prisoners may also be deprived of sending and receiving letters. Prisoners may also be placed in solitary confinement, which comprises the confinement of prisoners in complete isolation for 24 hours. This may continue for up to 15 days. All prisoners have the right to appeal against disciplinary punishment decisions. Governors also have the right to impose disciplinary measures. The following measures may be taken by the governor for disciplinary reasons:

1. The prisoner, with the proposal of the governor and participation of the prosecutor, may be transferred to another prison by the final decision of the general directorate for disciplinary reasons. 2. The governor may deprive the prisoner from participating in or watching social, cultural or sport activities.

3. The governor may change the place of work or occupation of the prisoner.

4. The governor may change the ward and the bed of the prisoner.

Source: Ministry of Justice, http://www.cte.adalet.gov.tr/. 